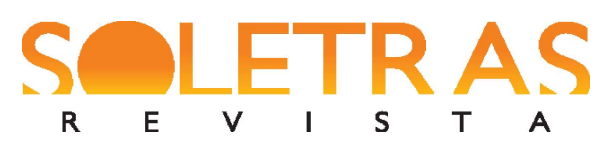

N. 40 - 2020.2 - CARMEM LUCIA NEGREIROS DE FIGUEIREDO

\title{
Ciência e nação. \\ Imprensa como observatório da cultura em Lima Barreto
}

\author{
Carmem Lúcia Negreiros de Figueiredo ${ }^{1}$
}

\begin{abstract}
Resumo: Afonso Henriques de Lima Barreto (1881-1922) é o escritor que, como poucos, apresenta forte ligação com periódicos que pode ser resumida em três aspectos ou faces: a incorporação de processos do jornalismo nos romances; a coleção de retalhos, ou recortes de jornais, ao lado das análises críticas da prática jornalística; e, ainda, a escolha dos jornais como tribuna para participar dos debates intelectuais na Primeira República. A partir da abordagem comparativa entre romances, cartas, diários e crônicas, é possível perceber a peculiar presença do jornal na criação literária e como fundamento para a atuação do escritor carioca na esfera pública. Este artigo analisa as formas como esse tenso e rico diálogo com os periódicos se realizou, destacando o debate sobre ciência e nação, que teve na imprensa sua melhor tribuna. As críticas de Lima Barreto aos métodos, interpretações e diagnósticos dos homens de sciencia trazem lições úteis que alcançam os nossos dias.
\end{abstract}

Palavras-chave: Lima Barreto. Jornalismo. Ciência. Nação.

\section{Introdução}

Afonso Henriques de Lima Barreto (1881-1922) é um dos escritores de mais forte ligação com jornais e revistas entre seus contemporâneos. Possui grande participação nos principais periódicos nas primeiras décadas do século $\mathrm{XX}$, escolhe colecionar recortes de jornais como método para criação literária e crítica cultural e, ainda, representa voz atuante sobre temas significativos no período tanto na imprensa de grande circulação quanto nos periódicos alternativos. Entre os principais debates que marcaram sua atuação na imprensa, destaca-se o impasse sobre o papel da ciência, os intelectuais e a (re)construção da nacionalidade na Primeira República.

\footnotetext{
${ }^{1}$ Professora associada da UERJ e bolsista CNPq e do programa Prociência FAPERJ/UERJ. Doutora e mestre em Teoria Literária pela UFRJ. Possui artigos publicados sobre Lima Barreto e, entre os livros, destacam-se o volume Lima Barreto, caminhos de criação (em parceria com Ceila Ferreira, EDUSP, 2017) e Lima Barreto em quatro tempos (Relicário, 2019). Coordena o LABELLE- UERJ. Brasil. E-mail: carmemlucianegreiros@gmail.com Orcid: https://orcid.org/0000-0002-0873-7731
} 


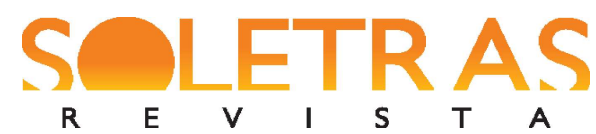

Ainda como estudante da Escola Politécnica, no Rio de Janeiro em 1903, colaborou nos humorísticos Tagarela e $O$ Diabo. Já em 1905, inicia uma série de reportagens intitulada $O$ subterrâneo do morro do Castelo ${ }^{2}$, publicada no jornal Correio da Manhã e, em 1907, começa a trabalhar na revista Fon-Fon! como redator. Em fins do mesmo ano, funda com amigos sua própria revista, Floreal, de efềmera duração, com somente quatro números publicados. Escreveu diariamente para o Correio da Noite, em 1914, e, em 1915, inicia a primeira fase de sua longa colaboração na revista Careta, que vai até 24 de junho de 1916. Vale lembrar que, em 1917, o escritor planejava criar outra revista, que se chamaria Marginália, mas o projeto não foi adiante.

Com o pseudônimo de Dr. Bogoloff, publica, em 1918, uma série de crônicas no vespertino A Lanterna. No mesmo ano, lança no periódico A.B.C. o seu "Manifesto maximalista" que termina com o grito de guerra "Ave, Rússia!", além de um conjunto de crônicas que perfazem mais de vinte títulos. Contudo, no ano seguinte, suspende sua colaboração no periódico pelo fato de ter sido publicado nele um artigo racista. Em março de 1919, começa a publicar no semanário Hoje crônicas acerca da cultura urbana carioca sob o título Mágoas e sonhos de um povo. Neste mesmo ano, inicia a segunda fase de sua colaboração na Careta, só interrompida com a morte.

Em maio de 1922, entrega ao editor Francisco Schettino os originais de Feiras e Mafuás (crônicas) e, em primeiro de novembro, falece no Rio de Janeiro. O fim de uma vida intensa de participação em jornais e revistas e na cena cultural e literária que se intercalava com a publicação de artigos, crônicas, contos e romances. Mais do que participar dos principais veículos de imprensa no período, Lima Barreto incorporou muitas técnicas vindas dos jornais em seus textos literários, colecionou recortes de jornais para estudo tanto da vida cultural quanto da linguagem dos periódicos como estratégia para a criação literária e fez dos jornais e revistas observatório peculiar da cultura brasileira.

\footnotetext{
${ }^{2}$ Léo Junius, pseudônimo de José da Rocha Leão, colaborador do Jornal do Commercio e da Gazeta de Notícias, reuniu e publicou no Correio da Manhã, em 1875, uma série de artigos sob o título Os Subterrâneos do Morro do Castelo, seus mistérios e suas tradições, reunidos em livro em 1878. Lima Barreto inspirou-se nesse material para criar sua obra que articula registros históricos, técnicas jornalísticas e ficção (utilizando-se das estratégias típicas do romance folhetim).
} 


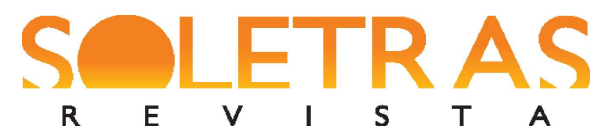

\section{Processos do jornalismo nos romances}

Há, durante a Primeira República, uma tensão entre os valores de uma burguesia urbana - em ascensão econômica, mas politicamente frágil - e o latifúndio poderoso e tradicional. Ao mesmo tempo, desestabilização e mobilidade crescentes marcam a capital do país com o espaço urbano cada vez mais fragmentado, perceptível por meio dos deslocamentos das viagens de trem, bonde, automóvel e do intenso fluxo de informação vindo dos jornais, letreiros e cartazes espalhados pelas ruas. Território onde já circulam signos e imagens separados de um referente com o recurso de técnicas diversas, na convergência de variadas tecnologias e novas funções tanto econômicas quanto simbólicas das imagens e produtos. A vivência emocional e o entretenimento tornam-se as linhas diretivas da atividade cultural, estratégia econômica para vender não mais o produto em si, mas uma atitude, um estilo, um padrão de comportamento, tornando a emoção e o prazer alicerces dos valores dirigidos para o consumo.

$\mathrm{Na}$ organização da imprensa, os traços de empresa capitalista já aparecem na relação do jornal com os leitores e na divisão interna de trabalho. Com as inovações técnicas que revolucionam os métodos de impressão, o crescimento das tiragens, a eficácia na distribuição e a organização de funções, vem em primeiro plano a informação, ao lado de nova categoria de jornalistas profissionais, caricaturistas e ilustradores. O incremento de novas seções, como moda e entretenimentos diversos, com ilustrações gráficas e fotografias, é estratégia comercial para a mobilização de lucros. Tais recursos, por outro lado, diminuem a importância e espaço de textos literários e críticos. Acontece, portanto, a reorganização do campo intelectual, com deslocamento do prestígio do literato na disputa com outras formas de discurso e poder. Nesse quadro dinâmico, a tensão se instala entre o homem de letras e o jornalista, estando em pauta a distensão de vários limites e o reposicionamento de lugares de poder. Não se trata somente de uma questão de renda, emprego ou visibilidade, mas do espaço de reconhecimento do sujeito literário no campo discursivo.

No interior das redações, na especialização de funções e divisões de poder, percebe-se "uma lógica de sentido profundamente fragmentária (...) constituída por uma acumulação de fragmentos de códigos, em que as linguagens se superpõem, se justapõem ou simplesmente se misturam, com discursos de todos os tipos e procedência histórica, impossível de definir" (RAMOS, 2008, p. 143). A variedade de seções e atrações dos jornais funcionava enquanto 


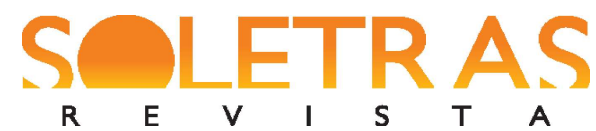

iniciação à leitura por meio de recursos como as ilustrações, a interpelação do leitor e a inserção de estruturas advindas das narrativas populares (eixo da literatura de cordel), especialmente relatos de crimes com os apelos sinestésicos na redação sensacionalista de notícias.

Já no romance de estreia, Recordações do escrivão Isaías Caminha ${ }^{3}$, Lima Barreto tensiona, na própria escrita, a fratura entre as diversas práticas discursivas. ${ }^{4}$ A linguagem que adota para o romance incorpora o ritmo do jornal (isso fica mais evidente na segunda parte da obra), explorando a ilusão de proximidade com o leitor construída pelo tom direto, períodos curtos, metonímias em sequência, diálogos breves e com expressões de uso comum. Esses elementos reunidos sugerem movimento e proximidade com os leitores, como se se tratasse da dramatização da rotina de pessoas deles conhecidas, numa analogia com o cotidiano. Ritmo de informação, com aprofundamento psicológico e imagens de folhetim. A escolha dessas técnicas na linguagem ${ }^{5}$ ficou em segundo plano para a maior parte da crítica, contemporânea e posterior ao lançamento do romance, que nele viu uma espécie de autobiografia mal resolvida ou uma crítica direta à imprensa, com estratégia de roman à clef.

Depois do lançamento do segundo romance, Triste fim de Policarpo Quaresma, em 1915, Lima Barreto recebe uma carta anônima em que o missivista acusa o escritor de utilizar “processos de jornalismo" nos seus romances. Na apresentação da coletânea de contos Histórias e sonhos o autor responde ao questionamento:

O meu correspondente acusa-me também de empregar processos do jornalismo nos meus romances, principalmente no primeiro.

Poderia responder-lhe que, em geral, os chamados processos do jornalismo vieram do romance; mas mesmo que, nos meus, se dê ao contrário, não lhes vejo mal algum, desde que eles contribuam por menos que seja para comunicar o que observo; desde que possam concorrer para diminuir os

\footnotetext{
${ }^{3}$ Os primeiros capítulos vieram a público em 1907, na revista Floreal, que, dirigida pelo escritor, sobreviveu até quatro números. A primeira edição em livro foi feita em Portugal em 1909 com alterações no texto à revelia do autor. A segunda edição publicada sob os cuidados de Lima Barreto aparece em 1917, com acréscimos e modificações.

${ }^{4}$ Exemplar desse recurso é a cena em que Isaías precisa ir a uma casa de prostituição informar ao diretor do jornal sobre o suicídio de um jornalista, o crítico literário Floc. Vale a pena acompanhar o movimento. Primeiro, a entrada na casa, a descrição da ambiência e das figuras ali presentes; depois, o mergulho no passado, provocado pelos objetos e prostitutas, o encontro com uma velha prostituta e, rapidamente, o corte com o diálogo direto e a informação passada ao diretor. Atmosfera impressionista que inspira sensações visuais e tácteis, ritmo ágil e quadro folhetinesco, sem faltar o quadro grotesco das figuras.

${ }^{5}$ Ver a respeito em Figueiredo e Ferreira (2017).
} 
motivos da desinteligência entre homens que me cercam (BARRETO, 1956, Histórias e sonhos, v. 6, p. 34)

Fica evidente a percepção do escritor sobre a força da ficção disseminada nas páginas dos jornais, que representaram, ao mesmo tempo, a inserção da sociedade brasileira enquanto consumidora de bens culturais do capitalismo editorial, ainda no século XIX, e a absorção das estratégias folhetinescas nos romances. Vale lembrar que os recursos literários folhetinescos, presentes nos romances canônicos e/ou nas muitas traduções de romances folhetins, foram importantes na orientação da sensibilidade de leitores e coerentes às necessidades de um público feito mais por ouvintes do que por leitores.

A coexistência e interpenetração entre romance e folhetim apresentam-se como particularidades da experiência cultural brasileira, fundada, primeiramente, no predomínio de um romantismo com dualismo de forças sociais, que sempre se resolve com solução mágica, com aventuras e intrigas, dissolvendo as contradições sociais, recurso ideal para uma cultura que almeja a feição cosmopolita e modernizadora, feita de trabalho escravo. Por outro lado, características literárias, como a facilidade e a ênfase, coadunam-se com um público de auditores, numa sociedade de iletrados, analfabetos e poucos afeitos à leitura. Segundo Antonio Candido (1980, p. 81), "a grande maioria de nossos escritores de prosa e verso, fala de pena em punho e prefigura um leitor que ouve o som da sua voz brotar a cada passo por entre as linhas". Incorporar as técnicas e estruturas do folhetim não significa uma deturpação ou desqualificação do romance enquanto gênero, uma vez que, considerado acanônico (BAKHTIN, 1988), o romance possui, entre as suas características de formação, o plurilinguismo, a plasticidade e a autorreflexão e, nessa perspectiva, considera sempre a autocrítica. O caráter inacabado marca, segundo Bakhtin (1988), o centro da orientação literário-ideológica do romance, fundamentada no nível de uma realidade atual, fluida, exploradora do presente, que permite tornar o aspecto subjetivo humano objeto de experiência e de representação. Ao lado da reconstituição histórica e/ou descrição dos costumes, o romance permite, ainda, o aprofundamento da investigação acerca do "eu", da educação da sensibilidade e do controle das emoções. Em meio a tais dilemas de âmbito formal, o romance realiza-se, no Brasil, na convergência do capitalismo como cultura, perceptível no cotidiano oitocentista - da moda à música -, com um mercado consumidor bastante movimentado, aliado à tecnologia da imprensa feita de uma cultura visual 


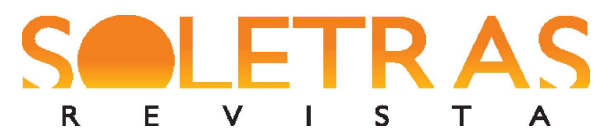

de muitos anúncios, que orientam o consumo e as atitudes, tudo reunido para formar o cenário de brasilidade. Contexto complexo que levou o crítico Roberto Schwarz (1988, p. 29) a afirmar que "o romance existiu no Brasil, antes de haver romancistas brasileiros", numa referência ao fato de os romances estrangeiros circularem no Brasil desde o século XVII, muito antes da fundação do romance nacional.

O que leva Lima Barreto a se aproximar dos chamados processos do jornalismo na literatura, além do tenso diálogo com essa tradição literária?

Lima Barreto sempre manifestou nas suas obras grande preocupação quanto aos efeitos da literatura e da leitura em um país de analfabetos, bem como ao lugar conferido pela sociedade ao intelectual. Sua atividade de escritor defende uma militância baseada na questão: "Em que pode a Literatura, ou a Arte, contribuir para a felicidade de um povo, de uma nação, da humanidade, enfim?” (BARRETO, 1956, Impressões de leitura, v. 13, p. 55).

$\mathrm{Na}$ tentativa de produzir literatura com capacidade de, ainda, intervir na realidade, o escritor escolheu transformar o tema em objeto de reflexão nas suas obras ficcionais, através das ações das personagens e reflexão dos narradores, assim como debatê-lo em crônicas e artigos. Por isso, é frequente nos seus textos a reflexão sobre os efeitos da literatura e da leitura na formação de jovens, na construção de sonhos no cotidiano ou na alienação dos sujeitos. Ao tratar da imprensa, na perspectiva do narrador do romance Recordações do escrivão Isaías Caminha, observa-se sua preocupação com certa finalidade de educação, e orientação, a ser cumprida pelo texto literário. Especialmente no momento em que se afirma o avassalador prestígio do discurso jornalístico sobre o discurso literário, seria preciso pensar o papel e função da Literatura na orientação da sensibilidade e, ainda, as explicações dos recursos técnicos usados nos jornais que encurtam, e muito, o saber narrativo para, em seu lugar, introduzir a informação.

Lima Barreto considera importante explicar ao leitor a elaboração do espetáculo, feito de palavras, que jogará os indivíduos à deriva nas ruas ou revoltados em motins; expor como se faz a ascensão e/ou destruição de figuras públicas e reputações em troca de privilégios, vantagens e lucros; detalhar as etapas e a formatação de um texto jornalístico, com explicação quase didática sobre a folhetinização da notícia ${ }^{6}$, entre outros elementos. Tal processo de

\footnotetext{
6 'Feita com a moral de Simão de Nântua e a leitura de folhetins policiais, a 'cabeça' é a pedra de toque da inteligência dos pequenos repórteres e dos redatores anônimos. (...). Por fím, chegou Leporace e lembrou um
} 


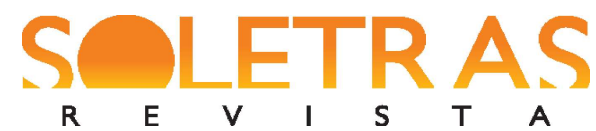

orientação atende à finalidade conferida pelo escritor à Literatura - a de formar e intervir sobre o leitor e a realidade. Essa opção produz um dilema: a consciência crítica dos limites impostos ao discurso literário - frente a outros poderosos discursos - simultaneamente ao desejo de ainda torná-la prestigiosa, com forte poder de formação sobre os indivíduos. Se o romance problematiza a própria impossibilidade de narrar, como nos romances do século XIX, frente a uma realidade fragmentada, intensa e diante do questionamento da noção de subjetividade, os motivos da crise no prestígio do discurso literário precisam, segundo Lima Barreto, ser expostos e discutidos a partir de seus bastidores.

Como resultado, produz-se em seus romances o diálogo tenso com a tradição literária, desde a escolha de temas à incorporação de recursos e técnicas tão necessários para o envolvimento do leitor brasileiro, acostumado a ouvir notícias e ver imagens estampadas em jornais e almanaques. Assim como também incorpora as novas tecnologias de imagens que sugerem movimento e deslocamento sem precedentes, de acordo com as exigências da nova experiência urbana, para experimentar a força da literatura diante de tantos novos discursos e dispositivos.

Aponta, ainda, para a necessidade de novos métodos e perspectivas coerentes "ao acúmulo de ideias que trouxe o tempo, com as descobertas modernas que alargaram o mundo e a consciência do homem, e outros fatores mais" (BARRETO, 1956, Impressões de leitura, v.13, p. 64). A noção de beleza, por exemplo, em sua concepção, está melhor representada na sua época pela construção estética de Crime e castigo, de Dostoiévski, do que por conceitos arcaizantes do belo, inspirados pela Grécia clássica, tema frequente dos debates entre literatos no período. Para o escritor carioca, a arte, especialmente a Literatura, permite "explicar a dor dos humildes aos poderosos e as angustiosas dúvidas destes, àqueles" (BARRETO, 1956 Impressões de leitura, v. 13, p. 67). Para tal tarefa, o diálogo crítico com "os processos do jornalismo" torna-se imperioso.

título rocambolesco de romance popular: Descampado da morte! Boa ideia, gritaram todos; e Adelermo pôs-se a escrever" (LIMA BARRETO, 1990, p. 101-103). 


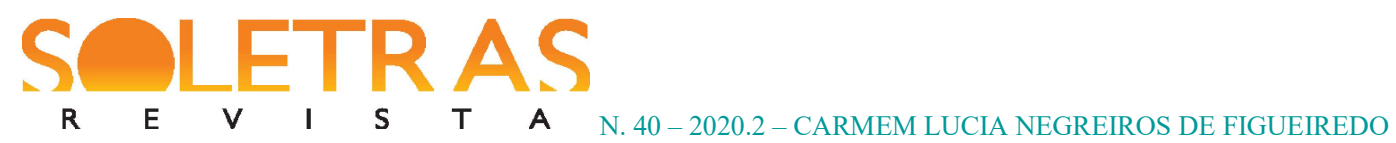

\section{O colecionador de "retalhos" e o jornalismo na berlinda}

No volume de crônicas Marginália, Lima Barreto explica seu método de colecionador, correlacionando os textos da crônica à "marginália", isto é, os comentários feitos à margem dos recortes de jornais colados no caderno. Ao final da primeira crônica - que trata da questão dos poveiros (pescadores portugueses, de Póvoa do Varzim, que exerciam o monopólio da pesca em alto mar sem se naturalizarem brasileiros), com dura crítica ao nacionalismo -, explica o método de investigação e análise dos temas de que serão feitas as crônicas apresentadas no volume.

Era tal a falta de uma segura orientação nos que se digladiavam, que só tive um remédio para estudá-la mais tarde: cortar as notícias de jornais, colar os retalhos num caderno e anotar à margem as reflexões que esta e aquela passagem me sugerissem. Organizei assim uma "marginália" a esses artigos e notícias. Uma parte vai aqui (BARRETO, Marginália, 1956, v. 12, p. 32).

O escritor expõe aos leitores que realiza uma seleção, pesquisa e um tipo de “arquivamento" peculiar: recortes de jornais colados em cadernos, ou seja, uma coleção de recortes de jornais acompanhados de poucas anotações manuscritas, intitulada pelo autor de Retalhos. Constitui interessante material em que se evidencia um método de criação e é sugerido um movimento entre os temas contidos nos recortes e os assuntos de crônicas e artigos, a configuração ficcional de personagens e enredos nas obras do escritor carioca. Além de colecionar a partir de sua própria seleção, o escritor informa que recebe muitos retalhos de presente, como os doados por "um bom velho de minha vizinhança, apaixonado pela leitura de jornais", que "deu-me uma porção de retalhos de vários jornais e épocas diversas" (BARRETO, Vida urbana, 1956, v. 11, p. 151).

Um dos exemplos de vinculação entre os Retalhos, a criação literária e a vida cultural, especificamente com a imprensa, pode ser evidenciado na crônica intitulada "O meu conselho", que integra o volume Feiras e mafuás. Toda a crônica expõe as etapas e os efeitos de seu método de colecionador e, nele, o acaso é critério importante. A crônica abre-se com a transcrição de um anúncio de jornal, escrito em francês, feito por um jovem inglês que procura 


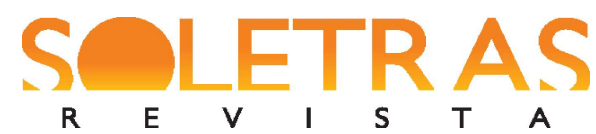

uma moça brasileira, "ilustre, artística e com dote" para casar. Apesar de residir em Trinidad, o postulante afirma estar interessado em acompanhar a moda na Europa e no Rio de Janeiro. O mais interessante é o relato de como encontrou o tal anúncio: “Topei com este anúncio, há dias, num retalho de jornal, com o qual ia embrulhar, 'abafar', como se diz caseiramente, alguns sapotis, para amadurecerem longe dos morcegos que (...) apreciam apaixonadamente tais frutas" (BARRETO, Feiras e mafuás, 1956, v. 10, p. 169).

A pretexto de comentar tal anúncio, recortado da Gazeta de Notícias em 15 de setembro de 1921, o autor faz na crônica uma interessante abordagem da história do Rio de Janeiro e suas relações com a Inglaterra, a presença da cultura inglesa no futebol, as demais manifestações culturais brasileiras em voga na capital. Belo exemplo do processo de criação literária que utiliza os recortes de jornais para tratar da cultura e, sobretudo, para expor os impasses da criação cultural. Como confidencia ao leitor, "quebrei a unidade do trabalho (Lima Barreto afirma que deveria escrever uma crônica e quase sai uma carta), mas pude ser confidencial e sincero" (BARRETO, Feiras e mafuás, 1956, vol. 10, p. 175).

Não cansa, portanto, de repetir em inúmeras situações, quer com seriedade, quer com ironia: "O jornal é uma fonte de estudos para mim. Nele tenho aprendido muito, menos elegância porque, ao que parece, Deus não quer que eu tenha esse dom extraordinário" (BARRETO, Vida urbana, 1956, v. 11, p. 249).

É também muito interessante a seleção feita por Lima Barreto dos anúncios publicados nos jornais antigos: todos referentes à compra e venda de escravos em leilões, trazendo aspectos histórico-culturais, entre eles, a promessa de alforria oferecida aos que se voluntariassem na Guerra do Paraguai.

Meses antes, em 10 de novembro do ano anterior [1868], na Rua da Alfândega $\mathrm{n}^{\circ} 100$, sobrado, alguém comprava escravos, de dezoito a trinta e seis anos, para serem libertos e assentar praça. Estávamos em plena guerra do Paraguai; e os patriotas que não queriam ir lá morrer, davam substitutos que iam combater o López por eles (BARRETO, 1956, Vida urbana, v.11, p. 155). 


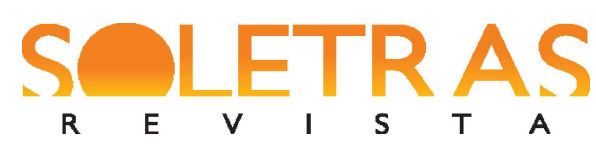

Nos anúncios de leilão de escravos, estes são listados como os móveis e animais "os escravos, animais, pratas e joias serão presentes na ocasião da praça”. O leilão de escravos anunciado nos jornais era ação rotineira nos oitocentos e as casas autorizadas para a tarefa faziam a descrição visual dos escravos como "mobília de segunda mão", entre pratarias, colares, móveis, anéis ou terras. Vendiam em geral os chamados "escravos ladinos", isto é, aqueles assimilados e capacitados a exercer diferentes funções domésticas, que se distinguiam dos recém-importados, sem habilidades e treinamento (KARASCH, 2000, p. 67).

A coleção desses textos-fragmentos, escritos em diferentes contextos, funções e para distintos destinatários, permite ao leitor a apresentação, por meio da crônica na página de jornal, de um interessante mosaico que ilumina aspectos de nossa história. Misturam-se na coleção retalhos de jornais antigos, com fragmentos de "apedidos" 7 e anúncios em seções que encantam o escritor na arrumação dos velhos retalhos: "Sempre gostei dos 'apedidos'. Dizem ser cousa peculiar ao Brasil, especialmente ao Rio de Janeiro. Seja usança boa ou má, o certo é que é cousa original, por isso gosto deles" (BARRETO, 1956, Vida Urbana, v. 11, p. 152). Entre os anúncios, destacam-se aqueles que tratam da venda de escravos.

E assim observamos que um conjunto de luzes discretas, hesitantes, frágeis emanam de anacrônicos retalhos de jornais permitindo rever a história sob os poderosos projetores da Belle Époque carioca. Os recortes de jornais, apartados de suas funções originais, funcionam como objetos integradores de lembranças, tanto pelo conteúdo que carregam como por seu aspecto visual, na disposição da colagem nas páginas e no aspecto envelhecido e desatualizado. ${ }^{8}$ Próximos do lixo, tornam-se vestígio e memória.

Além de colecionar recortes de jornais ou de discutir com os leitores o conteúdo dos periódicos, problematizando as questões nele apresentadas, Lima Barreto também realiza uma análise, por meio especialmente das crônicas, do formato dos jornais, suas seções, interesses e

\footnotetext{
${ }^{7}$ A seção "Publicação a pedidos" coaduna-se com os interesses e perfil dos leitores e com a prática política vigente na imprensa da Primeira República, cuja preocupação fundamental "não é a política, mas o fato político" (SODRÉ, 1983, p. 277). Representam um curioso espaço de confluência entre os recursos técnicos da empresa jornalística e o perfil dos leitores e/ou o encontro de uma de nossas mais antigas características culturais, isto é, a longa permanência da comunicação oral e ausência de libelos escritos com a modernização técnica. Antiga presença nos jornais, a seção representava o espaço para os leitores publicarem opiniões sobre personalidades, acontecimentos culturais, políticos e situações cotidianas; para estabelecer polêmicas a partir de ofensas e acusações; para declarações de amor, epigramas, exposição de trechos de poemas populares, com a linguagem avizinhando-se da obscenidade, do vulgar ou do absurdo.

${ }^{8}$ A expressão "desatualizado" justifica-se pelo fato de que Lima Barreto colecionava os retalhos de papel que também recebia de presente, não necessariamente jornais novos ou recém-lidos.
} 


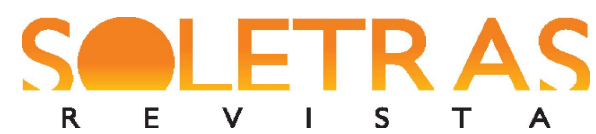

temas. Inicia a reflexão apontando que neles há "lacunas e "demasias" como, por exemplo, a grande quantidade de notícias oficiais (reportagens de ministérios, extratos de expedientes, relatos de atos de governo etc. que constituem "emprego inútil de espaço tão precioso" (BARRETO, 1956, Vida Urbana, v. 11, p. 54). Na mesma linha, seguem as críticas aos espaços destinados aos diários sociais, notícias da vida social e os "binóculos". "Existem a tomar espaço nos nossos jornais, uma outra bobagem. Além desses binóculos, há uns tais diários sociais, vidas sociais etc. Em alguns tomam colunas, e, às vezes, páginas. Aqui nesta Gazeta, ocupa, quase sempre, duas ou três" (BARRETO, 1956, Vida Urbana, v.11, p.54).

Outro aspecto interessante apontado por Lima Barreto trata da projeção a primeiro plano da vida íntima de anônimos, cujas ações, emoções e opiniões tornam-se públicas e são tratadas com relevância por revistas e jornais. "Tipos ricos e pobres, néscios e sábios, julgam que as suas festas íntimas ou os seus leitores têm um grande interesse para todo mundo" (BARRETO, 1956, Vida Urbana, v. 11, p. 54). Prossegue, chamando a atenção para o excesso de notícias policiais: "Dias há que parecem uma morgue, tal é o número de fotografias de cadáveres que estampam, e não ocorre um incêndio vagabundo que não mereça as famosas três colunas - padrão de reportagem inteligente. Não são bem "Gazetas" dos Tribunais, mas, já são um pouco Gazeta do Crime e muito Gazetas Policiais (BARRETO, 1956, Vida Urbana, v. 11, p. 55, destaque no original). E lamenta: "Enquanto isso, coisas da própria cidade não são tratadas convenientemente" (BARRETO, 1956, Vida Urbana, v. 11, p. 56).

Tomar os jornais como referência é tão caro à produção literária de Lima Barreto que podemos encontrar em suas crônicas formatos diversos sobre o tema, desde a criação de personagens que transformam o leitor em parceiro de conversa até o relato detalhado e crítico de notícias e matérias lidas nos diferentes periódicos.

Em Vida Urbana, assistimos o narrador apresentar uma personagem que segue os conselhos de um tal primo Augusto: tornar-se redator de jornal para ser apreciado "pelas moças da alta roda carioca" (BARRETO, 1956, Vida Urbana, v.11, p. 113). O protagonista relata que começa a carreira no interior, com muito sucesso por meio da coluna "A vida chic", mas como na sua "cidade natal não tinha casa de chá, nem Rua do Ouvidor, nem banquetes do Assírio, pois lhe faltava uma Secretaria do Interior para manter um luxuoso restaurant igual ao do porão do Teatro Municipal...” (BARRETO, 1956, Vida Urbana, v. 11, p. 113), resolveu 


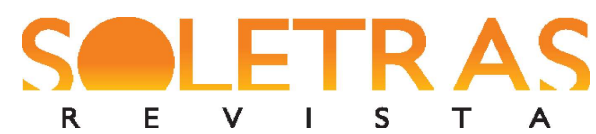

tentar a sorte na capital. A narrativa mostra com muito bom humor que a personagem alcança, depois de muitas peripécias e fracassos, a função de redator do jornal 'do bicho' intitulado $O$ Palpite. Como resultado, "cartas choviam" e, entre elas, "uma perfumada". Conclui: "De forma que com o palpite no bicho consegui o que não tinha obtido com a seção elegante: um amor" (BARRETO, 1956, Vida Urbana, v. 11, p. 114).

O observatório crítico da imprensa criado por Lima Barreto movimenta-se em muitos lugares, funções e formatos. Nas ruas, demonstra irritação com a ausência de pontos físicos para vendas de jornais que se amontoam nas esquinas da cidade, impedindo a circulação ou transformando as ruas em "mostruário de cotidianos" e, por isso, reclama a necessidade de "quiosques" especiais para a venda, espaço que, hoje, nós chamaríamos banca de jornal (BARRETO, 1956, Vida Urbana, v. 11, p. 71). Na cela - é assim que o escritor chama o espaço do Hospital Central do Exército quando esteve internado -, lê e comenta diversos periódicos ali disponíveis, questionando a fragilidade da formação de jornalistas e a imprecisão no conteúdo dos debates. Em destaque, a leitura crítica de um artigo de fundo de $O$ País, escrito para combater o chamado maximalismo russo e a revolução bolchevique. Lima Barreto contrapõe aos argumentos do jornalista uma exposição de aspectos da história cultural brasileira e a explanação de profundo conhecimento das teorias e filósofos, de Rousseau a Nietzsche, citados de maneira equivocada pelo autor do artigo.

Ao argumento do jornalista de que as altas classes russas estavam debilitadas pela vodka, ao contrário dos brasileiros "mais sadios", "mais equilibrados”, Lima Barreto comenta:

O sábio plumitivo, ao afirmar essas cousas de "vodka", de "sadio", de "equilibrado", a nosso respeito esqueceu-se que a nossa gente humilde, e mesmo a que não o é totalmente, usa e abusa da "cachaça", aguardente de cana (explico isto porque talvez ele não saiba), a que é arrastada, já por vício, já pelo desespero da miséria em que vive graças à ganância, à falta de cavalheirismo e sentimento de solidariedade humana do nosso fazendeiro, do usineiro e, sobretudo, do poder oculto desse esotérico Centro Industrial e da demostência Associação comercial, tigres acocorados nos juncais, à espera das vítimas para sangrá-las e beber-lhes o sangue quente. Esqueceu-se ainda das epidemias de loucura coletiva (Canudos, na Bahia; Muckers ${ }^{9}$, no Rio

\footnotetext{
9 A chamada Revolta dos Muckers foi um conflito regional que aconteceu, ao final do século XIX, em São Leopoldo (atual Sapiranga), na então Província do Rio Grande do Sul, no Brasil. Os Muckers foram um grupo de imigrantes alemães envolvidos em um movimento messiânico liderado por Jacobina Mentz Maurer e seu marido,
} 


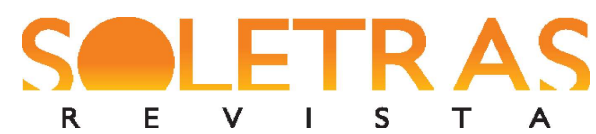

Grande do Sul etc.); esqueceu-se também do senhor doutor Miguel Pereira ("O Brasil é um vasto hospital").

Esquecendo-se dessas coisas comezinhas que são do conhecimento de todos, não é de espantar que afirme ser o anarquismo os últimos vestígios da filosofia (não ponho a chapa que lá está) do Contrato Social de Rousseau.

Pobre Jean-Jacques! Anarquista! Mais esta, hein, meu velho? (BARRETO, 1956, Bagatelas, v. 9, p. 104).

Para completar a argumentação no debate com o articulista e suas impropriedades teóricas, o escrito cita de cor uma passagem de Nietzsche para explicar ao jornalista, e ao leitor, a vulgarização do conceito de super-homem na prática que o escritor carioca denomina de "sociologia de revistas".

Nessa prática, o parâmetro nem sempre é o conhecimento, mas a empatia de assinantes e leitores que garantem o sucesso de vendas, ao lado da maior agilidade na distribuição e produção de jornais e revistas, com anúncios publicitários que se espalhavam pela cidade. Alguns aspectos técnicos como a importação de máquinas, o incentivo à importação de papel, o incremento de recursos visuais (entre eles, os serviços fotográficos), o clichê em cores, a linotipia, o telégrafo e o contato com agências internacionais de notícias ampliam atrações para o público consumidor. No entanto, a incorporação das tecnologias, a busca do lucro e a distribuição de seções, temas e linguagens para os mais diversos perfis de consumidores não foram suficientes para gerar uma política editorial consistente, tampouco livrar os jornais e revistas de medidas de controle, que variavam desde a censura difusa até o radical fechamento de redações e perseguição a jornalistas.

Em meio a tantos discursos e tendências com pretensão a orientar e explicar a nova realidade urbana (e o país), Lima Barreto participa do debate, em seu tempo, elegendo o jornal e a revista como observatório peculiar. Desse privilegiado e movente ponto de vista, pôde apresentar ideias e propostas além de, sobretudo, indicar que a superfície do jornal expressa a descontinuidade, o apelo do instante, o dilema entre efemeridade e permanência, a coexistência entre arcaico e moderno, o mergulho no cotidiano e o diálogo tenso com a tradição. Vale

João Maurer. O conflito armado ocorreu no período de 1873 a 1874 entre tropas do governo e os integrantes da comunidade religiosa liderada pelo casal. O cenário da revolta foi a linha Ferrabraz, abrangendo as atuais localidades de Campo Bom, Lomba Grande e Novo Hamburgo. O movimento, as ações de seus participantes, os relatos das batalhas e as perseguições posteriores aos sobreviventes do conflito ainda pertencem a páginas obscuras da história brasileira, mas são revistas, hoje, com a publicação de diversas novas pesquisas. 


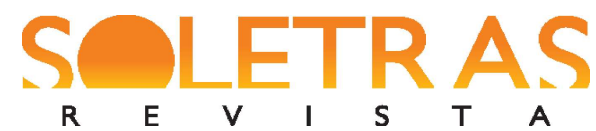

destacar também a intensa atividade intelectual do escritor, visto pela crítica, ainda hoje, como bêbado e boêmio indisciplinado, avesso à persistência e estudo. Ao contrário disso, vê-se uma trajetória de leitor, pesquisador de várias fontes e crítico das manifestações culturais e literárias atento à efervescência da Belle Époque e conhecedor profundo das tensões da tradição e dos marcos da memória.

\section{Jornalismo como tribuna: ciência e nação}

Os periódicos são a maior tribuna para o escritor Lima Barreto atuar no espaço público em torno de muitas questões, entre as quais destaca-se a pergunta: O que é o Brasil? Ou, ainda, quem são os brasileiros? Para respondê-las, muitos debates entre os intelectuais buscavam meios para a (re)construção da nacionalidade. Toda uma geração de perfil cientificista procurava argumentar junto à sociedade que os primeiros anos da República representavam o momento histórico de "fundação" ou "refundação" do país e regeneração do povo. Os intelectuais descobrem, desde o final do século XIX, "não sem perplexidade, a existência da diferença” (ABREU, 2010, p. 245). Tal descoberta foi marcada por eventos trágicos como Canudos, os Muckers e muitas outras revoltas abafadas com muita violência, mortes e desaparecimentos. Para a elite política e econômica, os males do Brasil estavam nas classes populares; suas tradições, crenças, cores e faces mostram a descendência de escravos abandonados à própria sorte nas terras do interior ou deambulando em busca de sobrevivência nas periferias das cidades. Seus hábitos e costumes foram considerados "incivilizados" e motivo de forte repressão policial. As doenças, resultantes das más condições de alimentação e moradia, tornam-se de imediato, para a elite, o grande obstáculo que impede o país de trilhar a via do progresso, fazendo-a abrir caminho ao sanitarismo comandado pelos médicos. A higiene seria instrumento de reforma social e moral do país. O discurso médico apresenta a proposta de intervenção biológica e, por meio da regeneração física e moral do indivíduo, promover a normalização do corpo social. Assume também a liderança para dirigir e normalizar a vida social e, com essa prática, o "Estado republicano decreta o fím da autonomia da família" e sinaliza para uma "intervenção social intensa, autoritária e sem fronteiras (HERSCHMANN, 1996, p. 12). 


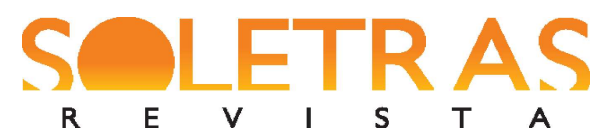

Todo esse conjunto de ações demonstra a transição de campos de conhecimento, isto é, a substituição da tipologia do clima como determinante para as doenças pela microbiologia, articulada à medicina tropical, para a institucionalização da ciência brasileira e atendimento das demandas da modernização. Em certa medida, tais ações realizam os sonhos positivistas acalentados desde a proclamação da República - um Estado guiado por homens de sciencia. Nesse contexto, entram em debate duas visões sobre o Brasil: a visão ufanista, de exaltação otimista do país, e a fatalista, inspirada nas teses de inferioridade racial. Os intelectuais ligados às campanhas de saneamento apresentavam uma tendência de crítica às teses do determinismo social. As lideranças dessas campanhas pelo país são representadas por Oswaldo Cruz (1872-1917), Carlos Chagas (1879-1934), Belisário Penna (1868-1939) e Arthur Neiva (1880-1934).

Apesar das dificuldades, Oswaldo Cruz realiza com êxito o combate à peste bubônica, varíola e malária na capital da República e, em 1903, é nomeado Diretor Geral da Saúde Pública e do Instituto Soroterápico Federal $^{10}$, promovendo a organização de expedições científicas para o interior do país. Essas viagens constituem o projeto de integração do interior brasileiro e preparam as bases de elaboração de nova ideia de nacionalidade. Designado por Oswaldo Cruz, o então jovem pesquisador Carlos Chagas parte para uma expedição científica ao norte de Minas Gerais em campanha de combate à malária. As pesquisas na região levaramno a identificar o agente causador, o trypanosoma cruzi, daquela que seria conhecida posteriormente como doença de Chagas. Realizou o estudo de todos os aspectos da moléstia: anatomia patológica, epidemiologia, etiologia, formas clínicas, meios de transmissão, patogenia, profilaxia e sintomatologia. Um ano após sua descoberta, recebeu o reconhecimento dos meios científicos internacionais. Depois da aposentadoria de Oswaldo Cruz, Carlos Chagas assume a direção do Instituto Soroterápico Federal, com destacada atuação na vida política como diretor desse Instituto (1917-1934) e dos serviços federais de saúde entre 1919 e 1926 (KROPFF, 2010, p. 57).

A doença de Chagas assume lugar significativo nos debates sobre o país, sendo classificada como a "doença do sertão" e chamando a atenção das elites para o isolamento tanto geográfico quanto cultural, o analfabetismo, a pobreza, o abandono e o atraso em

\footnotetext{
${ }^{10}$ Instituto Soroterápico Federal, criado em 1900 e também conhecido como Instituto de Manguinhos, a partir de 1908 passa a ser chamado de Instituto Oswaldo Cruz.
} 


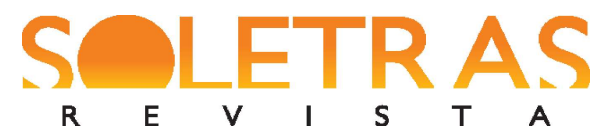

relação ao litoral tido como civilizado. Em 1916, o médico e professor da Faculdade de Medicina do Rio de Janeiro, Miguel Pereira, lançou durante uma conferência ${ }^{11}$ a famosa frase: “O Brasil ainda é um imenso hospital", incrementando o fervor nacionalista (no auge durante a Primeira Guerra Mundial) e temas como “ a questão racial, a imigração, a educação e, em especial, o recrutamento militar entrecruzavam-se na perspectiva de identificar as mazelas e as chances de regeneração do país" (KROPF, 2010, p. 68). Em fevereiro de 1918, foi criada a Liga Pró-Saneamento do Brasil, que congregou vários intelectuais e políticos da capital da República como resultado das pesquisas anteriores e da série de reportagens publicadas por Belisário Penna no jornal Correio da Manhã, ainda a partir de 1916 e reunidas no livro Saneamento no Brasil. ${ }^{12}$

Apesar das ações intelectuais, o fato decisivo para a intensificação das demandas pelo saneamento foi a gripe espanhola que atingiu o Brasil, mas desorganizou sobretudo a capital federal, entre outubro e dezembro de 1918.

\begin{abstract}
Além do grande número de mortes, a epidemia paralisou a vida da cidade, com falta de alimentos e remédios, carestia e a completa incapacidade das autoridades públicas em responder adequadamente. As descrições dos jornais, que foram submetidos à censura, são aterrorizantes. Faltavam coveiros e caixões para tantos mortos. Essa experiência de terror e medo causada por uma epidemia que atingiu as cidades sem muita distinção de classe social, ocupação ou região, com a autoridade pública revelando-se impotente ou despreparada, significou uma inflexão nas respostas até então dadas pelo Estado (LIMA e HOCHMAN, 1996, p. 35).
\end{abstract}

A divulgação pela imprensa do número de óbitos, da falta de assistência médica e do despreparo das autoridades para lidar com a doença intensificou o clima de medo e caos na cidade. A epidemia reforçou a necessidade de ampliação dos serviços sanitários, em âmbito nacional e com poder de intervenção, especialmente nas áreas rurais e periferias das cidades. E a chamada "Higiene" foi bastante criticada nos periódicos por não ter percebido o caráter francamente epidêmico da doença que já matava na Europa. Em 14 de outubro de 1918, o

\footnotetext{
${ }^{11}$ Pronunciou a frase em discurso de recepção a Aloysio de Castro, então diretor da Faculdade de Medicina do Rio de Janeiro, recém-chegado da Argentina, em outubro de 1916.

${ }^{12}$ Saneamento do Brasil, de Belisário Penna, lançado pela Typ. Revista dos Tribunaes, Rio de Janeiro, 1918.
} 


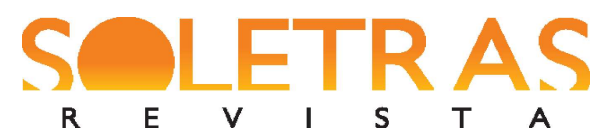

jornal Gazeta de Notícias publica com a manchete "A 'hespanhola' recrudesce", um panorama do quadro terrível na cidade, com a observação:

Os casos fatais que eram raros a princípio vão aparecendo em maior escala. E infelizmente como prevíramos, a segunda fase maligna do estranho mal com que a guerra, além de outras funestas consequências, nos presenteia sem que o mundo científico possa combatê-la eficazmente, por desconhecer-lhe a etiologia. E os seus efeitos ainda serão fatalmente mais desastrosos entre nós, dado o misto de desídia e incompetência que vem revelando o responsáve $1^{13}$ pelas nossas condições sanitárias (Gazeta de Notícias, 1918, p. $3)$.

Cabe acompanhar o registro da censura ao jornal e o informe aos leitores sobre a redução do número de páginas e seções do periódico porque muitos jornalistas estavam doentes. Ao lado do aviso, aparece a nota de abandono dos moradores do bairro do Catumbi, sem qualquer assistência médica. ${ }^{14}$

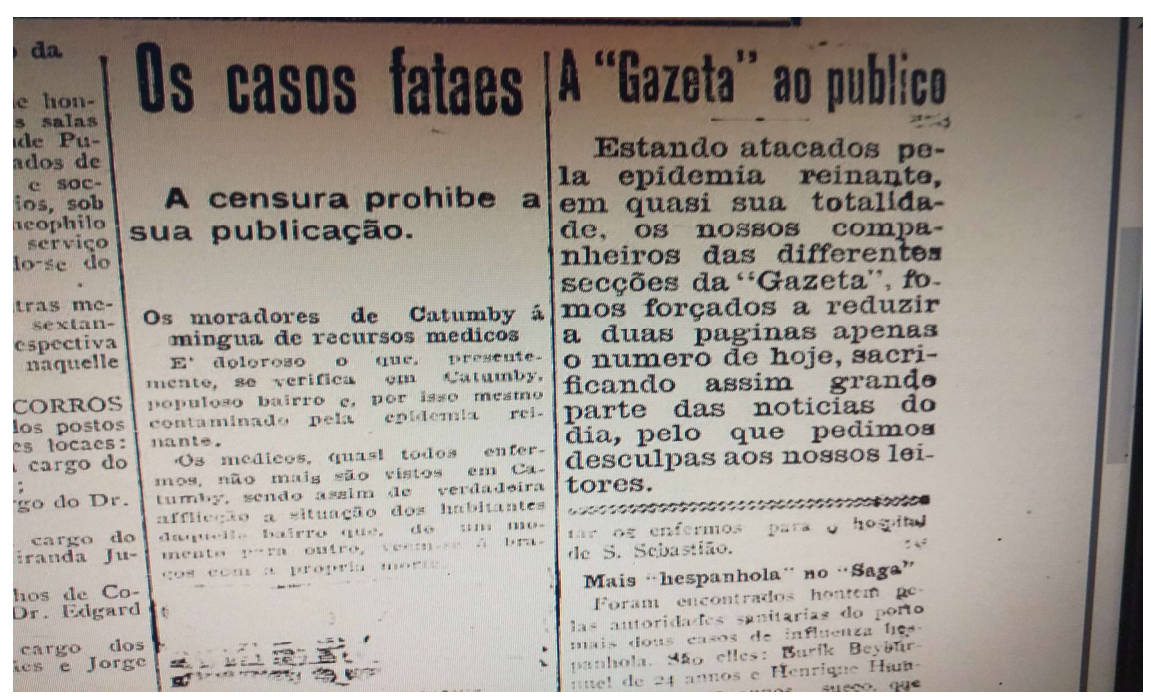

Fig. 1. Manchete: “A 'hespanhola' recrudesce”. Fonte: Gazeta de Notícias, 14 out. 1918. Disponível em: https://bit.ly/2TXuUfd. Acesso em: 23 maio 2020.

\footnotetext{
${ }^{13}$ O jornal refere-se a Carlos Seidl, então Diretor Geral da Saúde Pública.

${ }^{14}$ Gazeta de Notícias, 18 de outubro de 1918: "Os moradores de Catumbi à míngua de recursos médicos. É doloroso o que se verifica em Catumbi, populoso bairro e por isso mesmo contaminado pela epidemia reinante. Os médicos, quase todos enfermos, não são mais vistos em Catumbi, sendo assim de verdadeira aflição a situação dos habitantes daquele bairro que, de um momento para outro, veem-se a braços com a própria morte".
} 
As relações complexas entre ciência, saúde e sociedade são muito visíveis na cidade do Rio de Janeiro desde o início do século XX. A capital tornou-se espelho dos projetos político-pedagógicos liderados por médicos, e também por engenheiros e educadores, para traçar na cidade a linha reta, arborizada e limpa na direção do tão propagado progresso. As reformas urbanas entre os anos de 1903-1906, promovidas por Pereira Passos, prefeito, e Rodrigues Alves, presidente, transformaram vielas, becos, ruas estreitas e prédios coloniais em ruínas. A reforma do porto e a abertura das avenidas - do Cais, do Mangue e a Central tinham como meta a velocidade e a circulação de mercadorias, produzindo a desapropriação maciça no centro da cidade. A reforma urbana traduz a intenção de reforma social que projeta nos símbolos do passado da cidade e do país a inércia, o atraso, a doença, o feio. As reformas propõem "a utopia do novo tipificada por quatro ideias básicas: retilinidade, uniformidade, proporcionalidade, visibilidade (FABRIS, 2000, p. 44). Seus efeitos para a sobrevivência dos cidadãos mais pobres são tema frequente nas crônicas de Lima Barreto, publicadas em diferentes periódicos, sobretudo a especulação financeira, a carestia, a inflação que impossibilitava a moradia no centro da cidade e bairros adjacentes, empurrando a população para os morros. Para o cronista, na ótica do poder público, o bem-estar social não é prioridade.

Fala-se, por exemplo, na vergonha que é a Favela, ali, numa das portas de entrada da cidade - o que faz a nossa edilidade? Nada mais, nada menos do que isto: gasta cinco mil contos para construir uma avenida nas areias de Copacabana. (...). O Governo Federal - não há negar - tem sido paternal. A sua política, a respeito, é de uma bondade de São Francisco de Assis: aumenta os vencimentos e, concomitantemente, os impostos, isto é, dá com uma mão e tira com a outra. (...). O que parece atualmente é que o governo, seja municipal, seja federal, é impotente para resolver a carestia de vida e o encarecimento exorbitante dos aluguéis de casa (BARRETO, Marginália, 1956, v. 12, p. 185-186).

As ruas e avenidas ocupadas por grande quantidade de vendedores ambulantes, artistas mambembes, pequenos jornaleiros, capoeiras, prostitutas, variadas oficinas artesanais e ainda quiosques - que vendiam de roupas a bilhetes de loteria - alimentam o medo urbano mesclado ao fascínio pelo luxo de vitrines, automóveis e a moda projetada nos corpos em desfile. A 


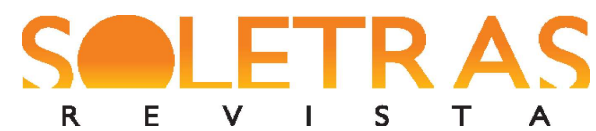

tensão só aumenta com a forte crise de habitação na mistura perversa de baixos salários e alugueis caros. "Um enorme contingente de homens vagava diariamente nas ruas do centro e arredores da zona portuária em busca de trabalho ocasional que lhes garantisse uma refeição no final do dia" (SANTUCCI, 2008, p. 49).

Nesse contexto, crescem as manifestações populares, reprimidas sempre com muita violência, desde a Revolta das Carnes Verdes (1902) à Revolta da Vacina (1904), entre outras, tendo desdobramentos como o uso político da insatisfação popular para tentativa de golpe de Estado e a resistência de habitantes do cais da Saúde na barricada conhecida como Porto Artur, além das primeiras greves operárias. "Ao reagirem à repressão governamental, os setores populares urbanos em revolta tentaram dar um basta à intervenção em suas vidas e à invasão mandatória de seus lares e de seus corpos, organizada por um governo com o qual em nada se identificavam” (PAMPLONA, 2010, p. 92). Nessa direção, campanhas de saúde, brigadas sanitárias, códigos municipais são instrumentos coercitivos para internalizar costumes modernos e ditos civilizados na população.

Revestido de conteúdo moral e religioso, o discurso da medicina torna-se instrumento catalisador de diferentes inquietações como: "medo de mudanças, despejo, pestes, vacina e suas implicações - como a invasão de moradias, violação da privacidade, física e moral (SANTUCCI, 2008, p. 106). Medos sociais e imaginários alimentados por boatos que a imprensa, por interesses e disputas político-partidárias, ajudava a disseminar.

Diante da complexidade do diálogo entre ciência e nação exercido sobretudo nos periódicos de diferentes perfis e tendências, como se posicionou Lima Barreto? São diversas as formas de manifestação do autor a respeito, em muitos momentos do conjunto da obra e publicações em jornais e revistas. Há em seus escritos a suspeita, como bom leitor de Nietzsche, sobre a propalada objetividade e certeza de bons resultados para todos os males da humanidade alardeada pela ciência. Dois aspectos marcam esse questionamento do escritor: a questão das raças e as explicações para a loucura. São dois grandes temas importantes no debate do período, quer pela problematização da nacionalidade, quer pela crise do sujeito soberano, abalado pelo processo de modernização da experiência urbana com invenções tecnológicas, deslocamentos espaçotemporais, transformações políticas e econômicas pelos quais "todo homem foi forçado a experienciar a sua própria insignificância” (KRACAUER, 2009, p. 118). 


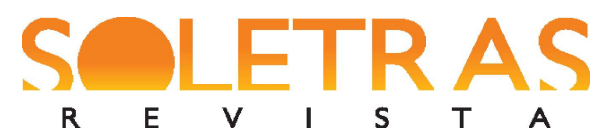

Se a atmosfera cientificista reunia tendências díspares entre si - de modelos biológicos e etnográficos ao naturalismo evolucionista e o positivismo francês -, além de organização de institutos e lugares de saber junto a espaços de poder - como quartéis, prisões, asilos, hospícios para enquadrar os sujeitos, controlar os riscos na cidade e desenhar um perfil de brasilidade -, o escritor carioca demonstrou, nas crônicas publicadas nos jornais, erudição suficiente e conhecimento das principais tendências no pensamento crítico. Nas discussões sobre ciência, cidadania e nação, os estudiosos e também literatos oscilam, em diferentes momentos de suas trajetórias intelectuais, do sanitarismo à eugenia, das teorias do determinismo biológico às primeiras noções do que ficará conhecido como democracia racial. E Lima Barreto acompanhava e participava dos debates com propriedade e argumentação pertinente, construída a partir de leituras feitas.

Há grande quantidade de observações em seus diários, correspondências e crônicas sobre ciência e biologização da raça vigente à época. "Se a feição, o peso, a forma do crânio nada denota quanto à inteligência e vigor mental entre indivíduos da raça branca, por que excomungará o negro?" (BARRETO, Diário Íntimo, 1956, v. 14, p. 61). Percebe-se sua clareza diante da proliferação dos determinismos raciais. "Vai se estendendo, pelo mundo, a noção de que há umas certas raças superiores e umas outras inferiores, e que essa inferioridade, longe de ser transitória, é eterna e intrínseca à própria estrutura de raça. Diz-se ainda mais: que as misturas entre essas raças são um vício social, uma praga e não sei que cousa feia mais" (BARRETO, Diário Íntimo, v. 14, p. 110).

Intelectual ativo, Lima Barreto enviou carta ao sociólogo francês Célestin Bouglé (1870-1940), discípulo de Durkheim e professor de Sociologia na Sorbonne, para contestar "os juízos falsos com que o mundo civilizado envolve os homens de cor". Diz o escritor: "ao ler seu belo livro, observei que o senhor está a par das coisas da Índia e pouco sabe sobre os mulatos do Brasil. Nas letras brasileiras, já florescentes, os mulatos ocuparam lugar de destaque. O maior poeta nacional, Gonçalves Dias, era mulato; o mais erudito dos nossos músicos, espécie de Palestrina, José Maurício, era mulato; os grandes nomes atuais da nossa literatura - Olavo Bilac, Machado de Assis e Coelho Neto - são mulatos" (BARRETO, Correspondência, 1956, tomo I, p. 158). O escritor demonstra também ter conhecimento das 


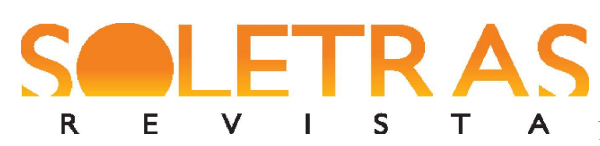

obras de Booker Taliaferro Washington (1856-1915), liderança afroestadunidense ${ }^{15}$ que, após a guerra civil, defendeu o ensino técnico como uma educação exclusivamente centrada no trabalho à população negra abandonada e sem perspectivas.

Em paralelo, há registros no Diário Íntimo de dores sofridas pelo racismo de que foi vítima. "Por que então essa gente continua a me querer contínuo, por quê? Porque...o que é verdade na raça branca, não é extensivo ao resto; eu, mulato ou negro, como queiram, estou condenado a ser sempre tomado por contínuo. Entretanto, não me agasto, minha vida será sempre cheia desse desgosto e ele me fará grande" (BARRETO, Diário Íntimo, 1956, v. 14, p. 52). É forte a preocupação do intelectual com a importante questão da cultura brasileira, especialmente no período em que as teorias de embranquecimento, entre outras, ganham forte apoio e defesa, concomitante à repressão violenta das manifestações culturais de matriz africana, sendo estas oprimidas, segregadas ou tornadas invisíveis, em nome do saneamento e da higiene em busca do progresso.

Lima Barreto age, utilizando diversos periódicos como tribuna, a partir do desejo de romper com o postulado do silêncio, ou do preconceito, sobre tal questão na literatura e nos debates intelectuais. Transcendendo a experiência pessoal, ou a partir dela, o escritor cria fissuras e tensionamentos em sua obra e no diálogo tenso com seus contemporâneos por meio das crônicas nos jornais para tratar de temas ligados ao que significa ser "mulato ou negro como queiram" no Brasil.

Em crônica de 16 de agosto de 1919 para o jornal A.B.C, Lima Barreto realiza uma longa exposição sobre os argumentos adotados pelos intelectuais para justificar a matança de grupos negros nos Estados Unidos e, indiretamente, naturalizarem o mesmo procedimento no Brasil e demais países em nome da ciência. A crônica começa com a citação do livro Le Préjugé des races (1906) do sociólogo francês, Jean Finot (1856-1922), um dos poucos

\footnotetext{
${ }^{15}$ Apesar do exitoso projeto de criação de escolas técnicas para negros em boa parte do território dos EUA, Booker Taliaferro Washington também foi duramente criticado por pensadores como William Edward Burghardt, conhecido como W.E.B Du Bois (1868-1963), autor do clássico As Almas do Povo Negro (1903) e considerado fundador da sociologia estadunidense - cujos trabalhos Lima Barreto também conhecia. Entre as críticas, pesa a acusação de não incentivar a formação universitária dessa população, a proposta de sujeição à política segregacionista e por não atuar de forma incisiva contra os frequentes linchamentos comuns à época.
} 


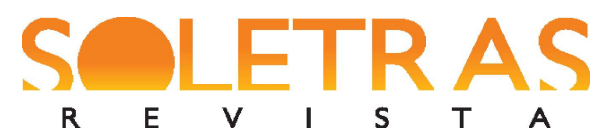

teóricos franceses contrários à teoria das raças no período. Vale a pena acompanhar alguns momentos do debate.

Nada mais falso do que apelar para a Ciência em tal questão. O que se chama Ciência nesse campo da nossa atividade mental ainda não é nem um corpo homogêneo de doutrinas. Cada autor faz um poema à raça de que parece descender ou com quem simpatiza, por isto ou aquilo.

(...)

Esses senhores que edificaram essas teorias de irremediável desigualdade de raças são tenazes e ferrenhos em remover todas as diferenças desta ou daquela natureza que possam separar o homem do macaco; mas, em compensação, são também tenazes e ferrenhos em acumular antagonismos entre os brancos e os negros. Às vezes mesmo, fazem enormes esforços para justificar, em teorias sociais, ódios de grupos humanos contra outros que, entretanto, têm diversa origem...

(...)

Com minha ignorância reconhecida, em alta de alguém mais competente, eu pretendi com essas linhas ligeiras dizer que a Ciência (com $\mathrm{C}$ grande) não autoriza, no seu estado atual, nenhuma matança de seres humanos, por serem desta ou daquela raça. Ela as autoriza tanto quanto os Evangelhos autorizaram as fogueiras de Sevilha, no tempo de Torquemada ou o Saint Berthélemy (BARRETO, 1956, Feiras e Mafuás, v. 10, p. 188-193).

Destaca-se também no conjunto de sua atuação nos jornais a problematização sobre as formas de controle e violência destinadas aos mais pobres, particularmente na capital da República, em nome do saneamento e do progresso. O escritor carioca ainda faz críticas veementes ao que denominou de "ditadura dos médicos".

A medicina é importante atividade intelectual, mas não é a única importante e não chegou a tal ponto de perfeição que os médicos tenham na cabeça ou nos livros as leis que regem as moléstias e a sua cura e a organização do Universo.

Se eles fossem verdadeiramente cientistas, haviam de ter dúvidas e nunca tentariam estabelecer na Terra a ditadura dos médicos, porque esta só seria válida se a medicina fosse uma verdade perfeitamente e completamente estabelecida.

Os médicos, os nossos, porém, não querem ver isso e arrotam a infalibilidade do laboratório, como se este não fosse, em última análise, óptica, física, cujas leis amanhã podem ser derrogadas ou mesmo revogadas. 


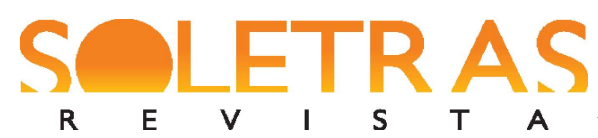

Demais, essas odiosas medidas, consignadas no tal Código $\mathrm{Negro}^{16}$, que a Saúde Pública ultimamente expediu, só visam os pobres, os desgraçados, os sem proteção...

(...)

Eles se esquecem que nós vivemos, no dizer de Renan, de velhas crenças que estão sendo abaladas, entre as quais está o poder e certeza certa da ciência (BARRETO, 1956, Feiras e Mafuás, v. 10, p. 56-60).

Lendo a crítica do escritor apressadamente, poderíamos até caracterizar sua atitude como a de um negacionista dos avanços e conquistas da ciência. Ao contrário, Lima Barreto realiza, como intelectual, a mediação entre as ideologias diversas e as necessidades dos cidadãos comuns. Há, na crítica, o olhar atento àqueles que na cidade habitam a zona de invisibilidade sem acesso às condições urbanas anunciadas pelos discursos da ordem, do progresso, da civilização. Atenta para a violência cometida contra os trabalhadores empobrecidos pela inflação e carestia provocadas pela grande especulação financeira; contra imigrantes e ex-escravos que deambulam pela cidade; contra mulheres e trabalhadores precários denominados de vadios pela repressão policial. Contingente grande de brasileiros, em sua maioria negros que, no auge do cientificismo, foram enquadrados numa categoria racial e biologicamente inferior. Por consequência, sofreram práticas discriminatórias no mercado de trabalho, no acesso à educação e toda a herança cultural que carregam é lida como manifestação de desocupados, incivilizados, bárbaros.

A população pobre é vista como a parte doente do corpo social que necessita ser saneada, disciplinada, com sua diversidade - e voz - silenciada, reprimida com violência. Intelectual humanista, o criador de Policarpo Quaresma suspeita do olhar pedagógico dos "missionários do progresso" e questiona, ao mesmo tempo, o aparato cientificista do controle sobre os sujeitos e a cultura. Afinal, na Primeira República, a "pobreza passou a significar sujeira, que significava doença, que significava degradação, que significava imoralidade, que significava subversão" (PATTO, 1999, p. 184). Longe de ser caracterizada somente como um mal do físico, a doença passa a ser "deteriorização da alma, da raça, que se traduzia nos mais

\footnotetext{
${ }^{16} \mathrm{O}$ escritor faz analogia entre o controle da Saúde Pública, com as rigorosas medidas de saneamento e higiene, e o Código Negro que definiu as condições de escravidão no império colonial francês. As regras dispunham sobre a proibição do exercício de qualquer outra religião que não o Catolicismo Romano, além de dar aos colonos o poder disciplinar sobre os escravos, incluindo legitimar punição corporal como um método de manter controle. A primeira versão do Código Negro foi promulgada em 1685 e a segunda em 1724.
} 


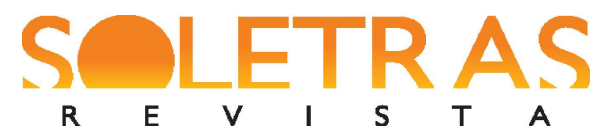

variados vícios: alcoolismo, promiscuidade sexual, negligência dos deveres paternos, vadiagem, crime, baderna anarquista. Doenças físicas, hábitos tidos como viciosos e sentimentos de revolta eram todos postos sob o mesmo rótulo de patologia" (idem).

$\mathrm{Na}$ ordem do dia, no cenário da Primeira República, também estava o debate sobre a educação como alavanca ao progresso, sendo tema importante para Lima Barreto. No entanto, o escritor sempre foi crítico do que se preconizava como "instrução pública", aquela que propõe ensinar a ler, escrever e fazer contas, apenas, sem qualquer premissa de conscientização. Ainda assim, inacessível para grande parte da população. “A municipalidade não dá mais livros, nem lápis, nem cadernos - não dá nada! Como é que os pobres pais pobres, ganhando o que mal dá para comer e morar, poderão arcar com as pequenas despesas de mantença de seus filhos no colégio primário?” (BARRETO, Marginália, 1956, v. 12, p. 112). Então podemos entender porque a cartilha sanitarista, que exige adesão imediata e irrestrita da população, não podia ser compreendida. No lugar da orientação e educação, entram duras medidas punitivas (e repressoras), que intimidam e não garantem formação social crítica.

É muito significativa a crítica do escritor, pois traz à tona questões estruturais da cultura brasileira, presentes ainda hoje e escancaradas no difícil momento da pandemia de COVID-19 e suas consequências. Os governos mantêm ações equivocadas, abandono das áreas urbanas pobres que sofrem com a ausência de condições de higiene básica e moradias inadequadas em locais densamente habitados. Além disso, os moradores dessas áreas continuam à mercê da repressão policial que, como nas primeiras décadas do século XX, ainda invade residências e pratica a violência em nome da segurança e bem-estar da cidade. $\mathrm{O}$ grande contingente de pessoas que habita as periferias das cidades brasileiras busca a sobrevivência enquanto vendedores ambulantes, sem qualquer apoio ou rede básica de segurança social (MUGGAH, 2020). Nesse aspecto, pouco melhoramos no Brasil. Lima Barreto, de seu observatório peculiar, nos traz o passado como continuidade e permanência.

A vida do homem e o progresso da humanidade pedem mais do que dinheiro, caixas-fortes atestadas de moedas, casarões imbecis com lambrequins vulgares. Pedem sonho, pedem arte, pedem cultura, pedem caridade, piedade, pedem amor, pedem felicidade; e esta, a não ser que seja um burguês burro e intoxicado de ganância, ninguém pode ter, quando se vê 


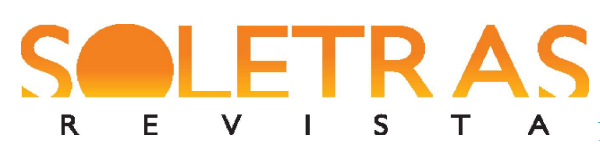

cercado da fome, da dor, da moléstia, da miséria de quase toda uma grande população (BARRETO, 1956, Bagatelas, v. 9, p. 164).

Por outro lado, Lima Barreto já problematiza o valor da ciência, fugindo da definição genérica e idealista de um conjunto de saberes unificados e com desenvolvimento autônomo. $\mathrm{Na}$ tribuna dos jornais, o escritor expõe a ciência não como prática neutra em si, mas como ação política cujas medidas refletem, dialogam ou se opõem a interesses e objetivos sociais bem definidos. Em momento de rica turbulência social e literária, o escritor procura nos jornais e revistas respostas a quais interesses as medidas científicas visam atender. Dito de outra maneira, por que a ciência se incorpora ao discurso governamental ou por que parece trocar os sinais de comunicação, isto é, por que segrega e oprime em nome da defesa da saúde e bem-estar social. Portanto, expõe as fissuras e tensões do conhecimento científico, afinal "a ciência não é assim um cochicho de Deus aos homens da Europa sobre a misteriosa organização do mundo" (BARRETO, Diário Íntimo, 1956, v. 14, p. 112).

Lição muito interessante a todos nós, leitores e leitoras do século XXI que sofremos, perplexos, a pandemia de COVID-19 e suas consequências, antes impensáveis, como a quarentena que paralisou o ritmo acelerado de mercantilização da vida. $\mathrm{O}$ vírus ensina que quando os princípios civilizatórios se afastam das decisões políticas, a ciência não pode produzir respostas apaziguadoras; apenas revela, em sussurro, nossa insignificância.

No caso brasileiro, o coronavírus deixou à mostra dois elementos estruturais de nossa cultura: o racismo que segrega e a violenta exploração econômica que sujeita todas as áreas destinadas a minimizar a desigualdade e o injusto sofrimento humano ao modelo de negócio do capital. Este, como já pontuava Lima Barreto, ignora princípios de cidadania e valores humanos, criando riquezas e consumo permeados de moléstia, abandono e miséria.

\section{Referências}

ABREU, Regina. Colecionando o outro: o olhar antropológico nos primeiros anos da República no Brasil. In: HEIZER, Alda; VIDEIRA, Antonio Augusto Passos (Orgs.). Ciência, civilização e república nos trópicos. Rio de Janeiro: Mauad X/Faperj, 2010. p. 245-255. 


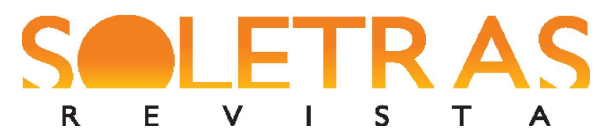

A 'HESPANHOLA' recrudesce. Gazeta de Notícias, Rio de Janeiro, 14 out. 1918. Disponível em: <http://memoria.bn.br/pdf/103730/per103730_1918_00289.pdf >. Acesso em: 25 maio 2019.

FIGUEIREDO, Carmem Lúcia Negreiros de.; FERREIRA, Ceila Maria (orgs.). Lima Barreto, caminhos de criação. São Paulo: Editora da Universidade de São Paulo, 2017.

BAKHTIN, Mikhail. Questões de literatura e de estética: a teoria do romance. Tradução por Aurora Fornoni Bernardini et al. 7. ed. São Paulo: Hucitec, 2010.

BARRETO, Afonso Henriques de. Histórias e sonhos. v. 6. Rio de Janeiro: Brasiliense, 1956.

BARRETO, Afonso Henriques de. Recordações do escrivão Isaías Caminha. São Paulo: Ática, 1990.

BARRETO, Afonso Henriques de. Impressões de leitura. v. 13. Rio de Janeiro: Brasiliense, 1956.

BARRETO, Afonso Henriques de. Marginália. v. 12. Rio de Janeiro: Brasiliense, 1956.

BARRETO, Afonso Henriques de. Vida Urbana. v. 11. Rio de Janeiro: Brasiliense, 1956.

BARRETO, Afonso Henriques de. Feiras e Mafuás. v. 10. Rio de Janeiro: Brasiliense, 1956.

BARRETO, Afonso Henriques de. Bagatelas. v. 9. Rio de Janeiro: Brasiliense, 1956.

BARRETO, Afonso Henriques de. Correspondência. Tomo 1. Rio de Janeiro: Brasiliense, 1956.

BARRETO, Afonso Henriques de. Diário Íntimo. v.14. Rio de Janeiro: Brasiliense, 1956.

CANDIDO, Antonio. Literatura e sociedade. São Paulo: Companhia das Letras, 1980.

FABRIS, Annateresa. Fragmentos urbanos: representações culturais. São Paulo: Studio Nobel, 2000.

HERSCHMANN, Micael. Entre a insalubridade e a ignorância. A construção do campo médico e do ideário moderno no Brasil. In: HERSCHMANN, Micael; KROPF, Simone; NUNES, Clarice (Orgs.). Missionários do progresso. Médicos, engenheiros e educadores no Rio de Janeiro (1870-1937) Rio de Janeiro: Diadorim Editora Ltda., 1996. p. 12-67.

KRACAUER, Siegfried. O ornamento da massa: ensaios. Tradução por Carlos Eduardo Jordão Machado e Marlene Holzhausen. São Paulo: Cosac Naify, 2009.

KARASCH, Mary C. A vida dos escravos no Rio de Janeiro (1808-1850). Tradução por Pedro Maia Soares. São Paulo: Companhia das Letras, 2000. 


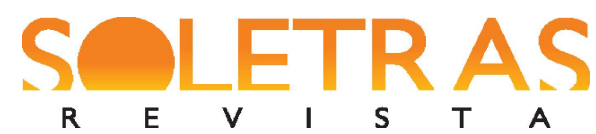

N. 40 - 2020.2 - CARMEM LUCIA NEGREIROS DE FIGUEIREDO

KROPF, Simone Petraglia. A descoberta da doença dos sertões: ciência e saúde nos trópicos brasileiros no início do século XX. In: HEIZER, Alda; VIDEIRA, Antonio Augusto Passos (Orgs.). Ciência, civilização e república nos trópicos. Rio de Janeiro: Mauad X/Faperj, 2010. p. 57-79.

LIMA, Nísia Trindade; HOCHMAN, Gilberto. Condenado pela raça, absolvido pela medicina: o Brasil redescoberto pelo movimento sanitarista da Primeira República. In: MAIO, Marcos Chor; SANTOS, Ricardo Ventura (Orgs.). Raça, ciência e sociedade. Rio de Janeiro: Fiocruz/Centro Cultural do Banco do Brasil, 1996. p. 23-40.

MUGGAH, Robert. Governos respondem a surtos de Covid-19 em favelas com punho de ferro ou negligência. Folha de S. Paulo, São Paulo, 27 de maio 2020. Disponível em: $<$ https://bit.ly/2Meotjz>. Acesso em: 27 maio 2020.

PAMPLONA, Marco A. A Revolta era a da Vacina? In: HEIZER, Alda; VIDEIRA, Antonio Augusto Passos (Orgs.). Ciência, civilização e república nos trópicos. Rio de Janeiro: Mauad X/Faperj, 2010. p.81-95.

PATTO, Maria Helena Souza. Estado, ciência e política na Primeira República: a desqualificação dos pobres. Estudos avançados, v.13, n. 35, p. 167-198, jan./abr.1999. Disponível em: <https://bit.ly/3eCpr5y>. Acesso em: 18 dez. 2019

RAMOS, Julio. Desencontros da modernidade na América Latina. Literatura e política no século 19. Tradução por Rômulo Monte Alto. Belo Horizonte: Editora UFMG, 2008.

SANTUCCI, Jane. Cidade rebelde: as revoltas populares no Rio de Janeiro no início do século XX. Rio de Janeiro: Casa da Palavra, 2008.

SCHWARZ, Roberto. Ao vencedor as batatas. Forma literária e processo social nos inícios do romance brasileiro. 3. ed. São Paulo: Livraria Duas Cidades, 1988.

SODRÉ, Nelson W. História da imprensa no Brasil. 3. ed. São Paulo: Martins Fontes, 1983.

\title{
Science and Nation. Press as culture observatory in Lima Barreto
}

\begin{abstract}
Afonso Henriques de Lima Barreto (1881-1922) is the writer who, like few others, has a strong connection with periodicals that can be summarized in three aspects or faces: the incorporation of journalism processes in novels; the collection of scraps, or newspaper clippings, along with critical analyses of journalistic practice; and also the choice of newspapers as a platform to participate in intellectual debates in the First Republic. From the comparative approach between novels, letters, diaries and chronicles it is possible to perceive the peculiar presence of the newspaper in literary creation and as a basis for the carioca writer's performance in the public sphere. This article analyzes
\end{abstract}




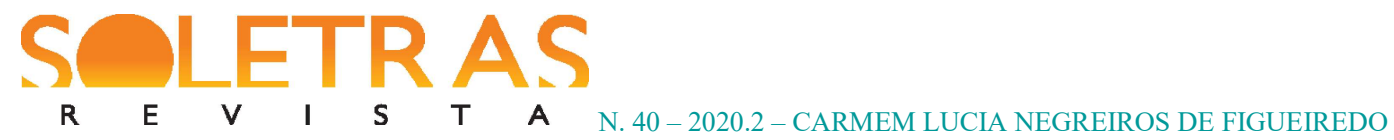

the ways in which this tense and rich dialogue with the journals took place and highlights the debate on science and nation, which had in the press its best tribune. Lima Barreto's criticism of the methods, interpretations and diagnoses of the so-called men of science bring useful lessons that reach our days.

Keywords: Lima Barreto. Journalism. Science. Nation.

Recebido em: 31 de maio de 2020.

Aceito em: 18 de junho de 2020. 